\title{
Measurement of iron and lead sulfide solubility below $100^{\circ} \mathrm{C}$
}

Figueroa Murcia, Diana Carolina; Fosbøl, Philip L.; Stenby, Erling Halfdan; Thomsen, Kaj

\section{Published in:}

Fluid Phase Equilibria

Link to article, DOI:

10.1016/j.fluid.2018.07.033

Publication date:

2018

Document Version

Peer reviewed version

Link back to DTU Orbit

Citation (APA):

Figueroa Murcia, D. C., Fosbøl, P. L., Stenby, E. H., \& Thomsen, K. (2018). Measurement of iron and lead sulfide solubility below $100^{\circ} \mathrm{C}$. Fluid Phase Equilibria, 475, 118-126. https://doi.org/10.1016/j.fluid.2018.07.033

\section{General rights}

Copyright and moral rights for the publications made accessible in the public portal are retained by the authors and/or other copyright owners and it is a condition of accessing publications that users recognise and abide by the legal requirements associated with these rights.

- Users may download and print one copy of any publication from the public portal for the purpose of private study or research.

- You may not further distribute the material or use it for any profit-making activity or commercial gain

- You may freely distribute the URL identifying the publication in the public portal 
Diana Carolina Figueroa Murcia ${ }^{1,2}$, Philip L. Fosb $\left.\varnothing\right|^{1,2}$, Erling H. Stenby ${ }^{1,3}$, Kaj Thomsen ${ }^{1,2^{*}}$

$3 \quad{ }^{1}$ CERE, Center for Energy Resources Engineering,

$4 \quad{ }^{2}$ Department of Chemical and Biochemical Engineering, Technical University of Denmark, DTU, Søltofts Plads 229, Kgs.

5 Lyngby, Denmark

$6 \quad{ }^{3}$ Department of Chemistry, Technical University of Denmark, DTU, Kemitorvet, Kgs. Lyngby, Denmark

$8 \quad *$ Corresponding author: Kaj Thomsen, kth@kt.dtu.dk

\section{Abstract}

11 The solubility of iron sulfide and of lead sulfide in water was determined experimentally in the temperature range from $25-80^{\circ} \mathrm{C}$ and at atmospheric pressure. The solubility of iron sulfide was determined by bringing precipitated iron sulfide in equilibrium with water and determining the concentration of iron ions and of total sulfur after the equilibration. The same method was used for determining the lead sulfide solubility in water. In both cases, a difference between the concentrations of metal ion and of total sulfur was observed. The concentrations were determined by inductively coupled plasma optical emission spectrometry (ICP-OES). The time required for equilibration was studied. The particle size distribution was examined to select a proper membrane for separating saturated solution from solid material.

Key words: Iron sulfide; Lead sulfide; Solubility in aqueous solutions; Scaling materials.

\section{Introduction}

22 The presence of zinc, lead, and iron plus $\mathrm{H}_{2} \mathrm{~S}$ can trigger the formation of scale materials such as Zinc 23 Sulfide ( $\mathrm{ZnS})$, Lead Sulfide (PbS), and Iron Sulfide (FeS). The solubility of these compounds is very low compared to other scaling materials such as $\mathrm{CaCO}_{3}$ or $\mathrm{BaSO}_{4} . \mathrm{H}_{2} \mathrm{~S}$ can be naturally occurring or be the result of sulfate-reducing bacteria [1]. The presence of iron can be natural or as the result of corrosion.

27 The prediction of the occurrence of sulfide scaling materials in oil production or geothermal energy facilities comes as a solution to avoid unnecessary production losses and costly shut downs due to 
incrustations during the life-time of a well. An accurate prediction of the solubility requires a highly reliable set of solid-liquid equilibria data and a robust thermodynamic model.

Iron exists in aqueous solution as the hexaaquo $\mathrm{Fe}\left(\mathrm{H}_{2} \mathrm{O}\right)_{6}{ }^{2+}$ ion in which the coordination of iron is octahedral. In aqueous solution, sulfide exists in the form of $\mathrm{H}_{2} \mathrm{~S}(\mathrm{aq}), \mathrm{HS}$, and $\mathrm{S}^{2-} . \mathrm{H}_{2} \mathrm{~S}$ dominates at acidic $\mathrm{pH}$ while $\mathrm{HS}^{-}$is mainly present in alkaline solutions. The sum of the amounts of these three sulfur species constitute total sulfur. Due to uncertainty of the value of $\mathrm{pKa}_{2}$ for $\mathrm{H}_{2} \mathrm{~S}$, we have followed new scientific findings of May et al. [2] and do not include $S^{2-}$ in low temperature aqueous chemistry. Instead, the solubility of metal sulfides is described in terms of HS $^{-}$in Eq. (1) as follows[3]:

$$
M S(s)+H^{+} \leftrightarrow M^{2+}+H S^{-}
$$

Where $M$ symbolizes the metal ion.

12 Iron sulfide is present in several crystalline forms such as mackinawite $\mathrm{FeS}_{(1-\mathrm{x})}$, troilite FeS, pyrrhotite $\mathrm{Fe}_{(1-x)} \mathrm{S}$ (mono-sulfides: only stable in absence of oxygen) pyrite $\mathrm{FeS}_{2}$ (cubic) and marcasite FeS orthorhombic (iron disulfides). Iron sulfide is often present in oil reservoirs and is also found in water reservoirs [4-6].

The solubility of mackinawite $\mathrm{FeS}_{(1-\mathrm{x})}$, troilite $\mathrm{FeS}$, pyrrhotite $\mathrm{Fe}_{(1-\mathrm{x})} \mathrm{S}$ (monoclinic and hexagonal), and pyrite $\mathrm{FeS}_{2}$ was determined by Tewari et al. [7]. Rickard [3] described solubility measurements of insitu precipitated FeS. Berner [8] studied the solubility product of FeS at $25 \pm 0.1{ }^{\circ} \mathrm{C}$. For his measurements, Berner used 4 crystalline forms of FeS (greigite, mackinawite, precipitated FeS and pyrrhotite).

Solubility data for FeS at high pressure and/or high temperature are scarce in the open literature. Yan, et al. [9] studied the solubility of troilite at $\mathrm{HP} / \mathrm{HT}$ reservoir conditions $\left(100^{\circ} \mathrm{C}-250^{\circ} \mathrm{C}\right.$ and 336.6 bar - 1654.7 bar). It was observed that the solubility of iron sulfide increases as the pressure increases. Meanwhile the effect of temperature on the iron concentration is inverse. The presence of $\mathrm{NaCl}$ in the solution causes the solubility to increase.

Iron sulfide scaling can be formed as a consequence of corrosion in the well as well as deposition of soluble Fe and $\mathrm{H}_{2} \mathrm{~S}$ present in the well. Iron sulfide scaling is usually present in $\mathrm{H}_{2} \mathrm{~S}$ rich oil wells (sour oil) and gas wells $[5,10-12]$. The main source of iron in an oil reservoir is from the corrosion process 
of the tubing. Other sources include drilling fluids and drilling muds [10]. $\mathrm{H}_{2} \mathrm{~S}$ present in the HP/HT reservoirs comes from different sources: bacterial reduction of sulfates present in the reservoir by sulfate-reducing bacteria, thermal cracking of sulfur organic compounds, thermo-chemical sulfide reduction and decomposition of working fluids [13-15].

\section{Previous studies on PbS solubility}

6 Lead sulfide is formed after the reaction of lead present in the formation waters or from external sources such as decomposition of inhibitors. Lead sulfide scaling has been located typically near the wellbore, production tubing and at the downhole safety valves as reported by Baraka-Lokmane et al. [13].

Naturally occurring lead sulfide is known as galena and it is characterized by a cubic crystal structure.

11 An orthorhombic form of lead sulfide has been identified but according to Clever and Johnston [16]

12 it only exists at high pressures (25000 bar).

13 Weigel [17] measured the solubility of both precipitated and natural PbS mineral using conductivity measurements. The solubility of the former is higher than the one of the latter. Nims and Bonner [18] determined the solubility of $\mathrm{PbS}$ by means of electromotive force measurements in concentration cells. Hamann and Anderson [19] measured PbS solubility in sulfur-rich $\mathrm{NaCl}$ solutions. They explored the solubility at two temperatures: $25^{\circ} \mathrm{C}$ and $90{ }^{\circ} \mathrm{C}$. Barrett and Anderson [20] reported experimental determination of $\mathrm{PbS}$ solubility using a precipitated form of $\mathrm{PbS}$ which was obtained by bubbling $\mathrm{H}_{2} \mathrm{~S}$ through a $\mathrm{PbCl}_{2}$ solution. The solubility data reported were obtained at a salinity range from 3 to 5 molal $\mathrm{NaCl}$.

We present solubility measurements for $\mathrm{FeS}$ and $\mathrm{PbS}$ at atmospheric pressure in a range of temperatures from 25 to $80{ }^{\circ} \mathrm{C}$. The methodology employed here was already tested in an earlier study on ZnS showing reliable results Figueroa et al. [21]. The measurements were carefully carried out in anoxic conditions. A consistent analysis of particle size of the initial solid is presented as the lack of this characterization is believed to be one of the main limitations found in the data previously published in literature. The characterization of the initial solid in terms of composition and crystal form was performed to provide a more accurate description of the solubility behaviour. 
3 The experimental set up used for measuring the solubility of FeS and PbS is described in detail in

4 Figueroa et al. [21]. The set-up consists mainly of three parts: 1 . An equilibrium cell coupled to a 5 thermostatic bath to guarantee constant temperature during experiments; 2 . A jacketed pipe to 6 transfer the sample from the equilibrium cell to the filtration unit at constant temperature and 3. A 7 jacketed two body filter for filtration at constant temperature. The pore size of the filtration 8 membrane was $0.2 \mu \mathrm{m}$.

\subsection{Materials description}

10 The starting material for measuring the solubility of FeS and PbS were the precipitated forms of FeS and $\mathrm{PbS}$ provided by Sigma-Aldrich. The purities of the materials were FeS (99.9\% trace metals basis)

12 and $\mathrm{PbS}$ (99.9\% trace metals basis). The samples provided by Sigma Aldrich were not packed in anoxic 13 containers. Oxygen may cause oxidation on the surface of the particles. The crystal structures of FeS 14 and PbS were determined by X-Ray Diffraction (XRD). A particle size analysis of the starting material 15 was run to determine accurately the required pore size of the filtration membrane. See Table 1 for 16 further details.

17 Table 1: Sample description table

\begin{tabular}{|l|l|l|l|}
\hline Chemical name & Source & Mass fraction purity & Purification method \\
\hline Iron Sulfide & Sigma Aldrich & 0.999 & none \\
\hline Lead Sulfide & Sigma Aldrich & 0.999 & none \\
\hline Nitrogen & AGA & $0.99999^{a}$ & none \\
\hline
\end{tabular}

a Mole Fraction

20 X-Ray Diffraction analysis was performed for FeS and PbS to identify their crystal structure. The XRD 21 patterns are shown in Figure 1. 
(a)

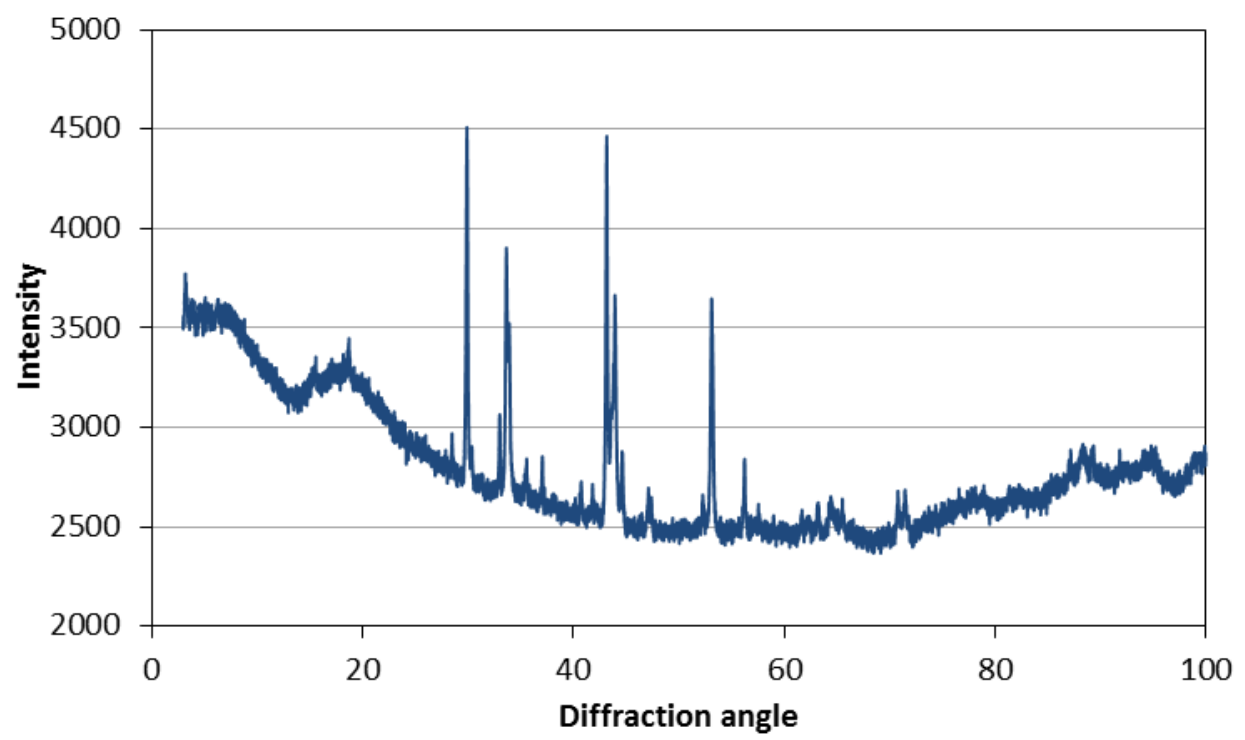

(b)

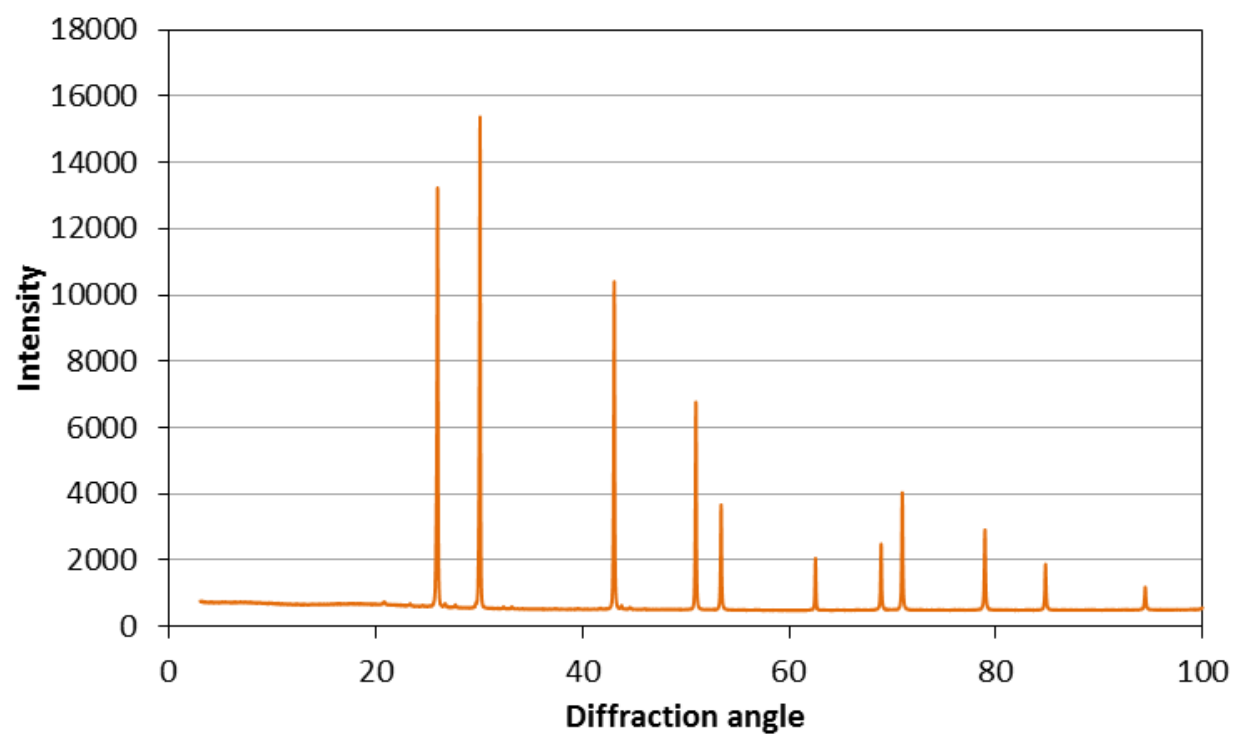

Figure 1: X-ray diffraction patterns of (a) Iron sulfide and (b) Lead Sulfide

2 The spectra for FeS (Figure 1a) identifies the starting material solid as FeS with less than

3 stoichiometric Fe. The compound is identified as synthetic pyrrhotite in its hexagonal form. The XRD

4 analysis suggests a formula of $\mathrm{Fe}_{0.98} \mathrm{~S}$ or $\mathrm{Fe}_{0.879} \mathrm{~S}$. The XRD analysis is a qualitative analysis and

5 therefore the pattern just proposes that the FeS starting material is pyrrhotite, containing slightly

6 less iron than sulfide.

7 Figure $1 \mathrm{~b}$ shows the XRD pattern obtained for $\mathrm{PbS}$. The pattern is more clearly defined than the one

8 obtained for FeS and the material was identified as synthetic Galena (PbS) in its cubic form. No other

9 compounds were found in the solid analyzed.

10 No other compounds than FeS and PbS were detected by XRD. Therefore, our solubility 11 measurements were carried out with the intended initial solid. No peaks referring to oxidized species 
were found in the XRD. Although increasing the time analysis of the samples might show some oxidized species (due to XRD analysis carried out in oxygen rich atmosphere). A rigorous procedure was followed to avoid the oxidation of the sulfides during solubility measurements (see Section 3).

\subsubsection{Particle size distribution}

5

6 The particle size distribution of FeS and PbS was determined using a laser diffraction method [22].

7 The results are presented in Figure 2. Figure 2 shows the particle size distribution of (a) FeS and (b)

$8 \quad \mathrm{PbS}$ measured at two different conditions.

(a)

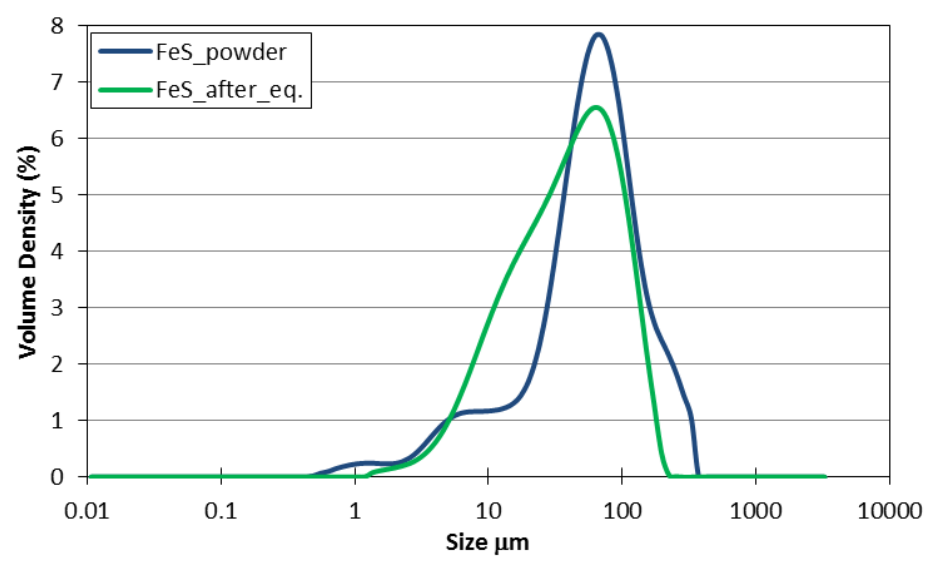

(b)

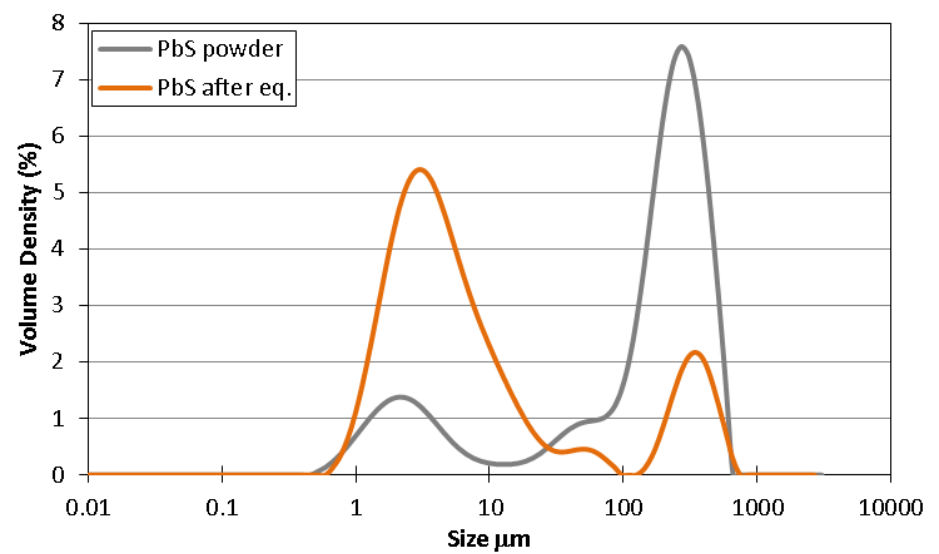

Figure 2: Particle size distribution of (a) FeS (b) PbS measured as initial solid (powder) and after equilibrium experiment

11 First, the solid was measured in powder form and secondly dispersed in ultra-pure water (after eq. conditions were achieved). The particle size of FeS in powder form is distributed between $0.38-330$ $\mu \mathrm{m}$. The $7.8 \%$ of the particles have a particle size of $62.7 \mu \mathrm{m}$. 
1 The FeS analyzed in dispersed form shows a similar distribution as the powder form. The particle size ranges from $1 \mu \mathrm{m}$ to $255 \mu \mathrm{m}$ with most of the particles having a particle size of $62.7 \mu \mathrm{m}$. Both analyses verify that the pore size of the membrane chosen is adequate since the results show there are no particles smaller than $0.22 \mu \mathrm{m}$.

5 In the case of PbS the particles in powder form are distributed between 0.46 and $3080 \mu \mathrm{m} .7 .6 \%$ of the particles have a size of $272.4 \mu \mathrm{m}$. This distribution confirms that $100 \%$ of the particles are larger than the pore size $(0.22 \mu \mathrm{m})$ of the filtration membrane used during the experiments. The distribution of the particle size after the equilibrium experiment is similar. No particles smaller than

$90.22 \mu \mathrm{m}$ are found, instead it is observed that PbS powder tends to form larger agglomerates, since the smallest particle size observed is $0.67 \mu \mathrm{m}$ (1.4 times larger than the smallest particle size in powder form). $5.48 \%$ of the particles in dispersed form have a size of $3.55 \mu \mathrm{m}$. These results confirm that no fine particles could pass through the filtration membrane.

During the assessment of the membrane pore size, large concentrations of Fe and $\mathrm{Pb}$ were measured in the filtrate. A reduction of the concentration of $\mathrm{Fe}$ and $\mathrm{Pb}$ up to $93 \%$ was in some cases obtained by using filters with the correct pore size.

\section{Methodology}

17 The methodology developed to determine the solubility of sparingly salts such as FeS and PbS is ranging from 25 to $80^{\circ} \mathrm{C}$ and atmospheric conditions. The methodology employed guarantees anoxic conditions to avoid the presence of oxidized species. Anoxic conditions are provided by preparing the sample in a glove box flushed with pure nitrogen (99.999\%) and stabilizing the solid using ultra-pure water previously degassed with pure nitrogen. In the case of FeS solubility, the ultra-pure water was first distilled and then degassed. This precaution was made since iron (II) can easily be oxidized to iron (III). Evaporation of water and of $\mathrm{H}_{2} \mathrm{~S}$ was avoided by addition of a silicone oil layer above the sample. The presence of interfering ions in contact with the solution was avoided by placing the aqueous solution in a propylene vial. No other substances were added either to control $\mathrm{pH}$ or to modify the salinity of the solution, since our intention is to study only the single interactions of FeS and $\mathrm{PbS}$ in aqueous solution. 
Filtration at the same experimental conditions and immediate dilution of the sample obtained was intended to prevent further precipitation of the solid phase after the equilibrium experiment. $\mathrm{pH}$ measurements were done after the filtration step prior ICP-OES analysis for PbS solubility experiments.

5 The concentration of $\mathrm{Fe}, \mathrm{Pb}$ and total sulfur were determined by ICP-OES. The concentrations presented in this study are above the detection and quantification limits. The detection limits are presented in Table 2.

Table 2 Detection limit for Fe and $\mathrm{Pb}[24]$

\begin{tabular}{lrr}
\hline & $\begin{array}{c}\text { ICP-OES Detection Limit* } \\
(\mathbf{m o l} / \mathbf{L})\end{array}$ & \multicolumn{1}{c}{$\begin{array}{c}\text { Wavelength } \\
\text { (nm) })\end{array}$} \\
\hline & \multicolumn{2}{c}{ Lower } \\
$\mathrm{Fe}$ & $1.11 \mathrm{E}-07$ & 259.939 \\
$\mathrm{~Pb}$ & $2.03 \mathrm{E}-07$ & 220.353 \\
\hline
\end{tabular}

12 The error estimation of the measurements is determined by measuring the concentration of $\mathrm{Fe}, \mathrm{Pb}$, and total $\mathrm{S}$ in a standard solution of known concentration. The error of the solubility measurements

14 is determined using the results of the measurements using the standard solution of e.g. iron as 15 follows:

$$
\text { Error }=\frac{C_{F e} e_{\text {(Std. solution })}-C_{F e}{ }^{\text {(Sample) }}}{C_{F e} e_{\text {(Std. solution })}} \times 100
$$

17 Where $C_{F e}$ (Std solution) refers to the known concentration of the element of interest in the standard

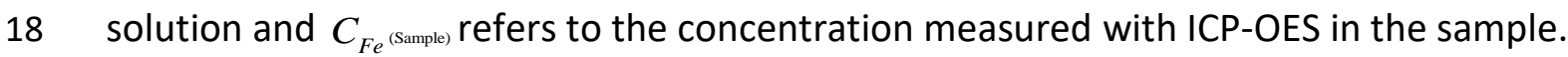

\section{Results and discussion}

20 The study of solubility of FeS and PbS is presented in two sections. First, the determination of the 21 necessary equilibration time at temperatures between $25^{\circ} \mathrm{C}$ and $80^{\circ} \mathrm{C}$ is reported. Then the influence of temperature on solubility and a comparison with previously published data is shown. 


\subsection{Equilibration time determination}

2 The equilibration time determination is a key factor in solubility studies. The equilibration time represents the time required to obtain a saturated solution and it is affected by temperature. By equilibration time we refer to the time at which no significant changes in Fe and $\mathrm{Pb}$ concentration are observed. At this time, we assumed that the dissolution process has ended and therefore the solution has reached equilibrium conditions. The solid and the aqueous phase were allowed to stay in contact for sufficient time (up to 14 days) to ensure that the dissolution process took place independently of particle size.

The results for FeS are presented in Figure 3 and for PbS in Figure 4 ; as molality $b\left(\mathrm{~mol} \cdot \mathrm{kg}_{\text {water }}{ }^{-1}\right.$ ) versus time at temperatures between $25^{\circ} \mathrm{C}$ and $80^{\circ} \mathrm{C}$. The data for FeS are reported in Table 3. It is observed in Figure 3 that the concentration of Fe and total sulfur remains almost constant in a range of time between 1 and 13 days at $25^{\circ} \mathrm{C}$ and $40^{\circ} \mathrm{C}$. At higher temperatures $\left(60\right.$ and $80^{\circ} \mathrm{C}$ ) the concentration of Fe and total S increases with time. An increase of 8.6 times is observed in the concentration of Fe from 1 day to 13 days at $40{ }^{\circ} \mathrm{C}$. A more significant increase is observed in Figure $3 \mathrm{~d}$ at $80{ }^{\circ} \mathrm{C}$ : the concentration of Fe is 42.3 times higher after 13 days compared to the concentration after 1 day. A plateau is not clearly identified at $60{ }^{\circ} \mathrm{C}$ neither at $80^{\circ} \mathrm{C}$. This suggests that the concentration of $\mathrm{Fe}$ and total sulfur may continue increasing over time. Figure $3 a$ and Figure $3 b$ show that the equilibrium conditions are achieved at around 6 days. This agrees with the studies on equilibration time for pyrrhotite done by Tewari et al. [7]. Tewari et al. [7] found that 7 days were required to achieve equilibrium conditions in the case of pyrrhotite.

The variation of the equilibration time with temperature suggests that equilibrium conditions are achieved faster at low temperatures $\left(25-40^{\circ} \mathrm{C}\right)$ than at higher temperatures $\left(60-80^{\circ} \mathrm{C}\right)$.

The variation of the concentration of total sulfur with respect to time exhibits the same behaviour as observed for Fe. There is a noticeable difference between the concentration of Fe and total sulfur.

This difference is observed to remain almost constant, meaning that the concentration of total sulfur is between 2.6 and 1.3 times higher than the concentration of Fe. It is interesting to note that there are larger differences between the concentration of total sulfur and Fe at low temperatures ( $25-40$ ${ }^{\circ} \mathrm{C}$ ) than at high temperatures $\left(60-80^{\circ} \mathrm{C}\right)$. No evidence of sulfur in significant amounts present in blank samples was found. The presence of sulfur containing contaminants can therefore be ruled out. Another hypothesis could be a difference in the composition of the starting material FeS. As 
1 mentioned in Section 2.1.1, the XRD analysis indicated that the starting FeS material contained less

2 Fe than S. This could explain some of the difference in concentration observed for Fe and total $\mathrm{S}$ in

3 Figure 3. The lower concentration of Fe than of total $\mathrm{S}$ can also be the result of precipitation of 4 another Fe compound such as an oxide or hydroxide.

(a)

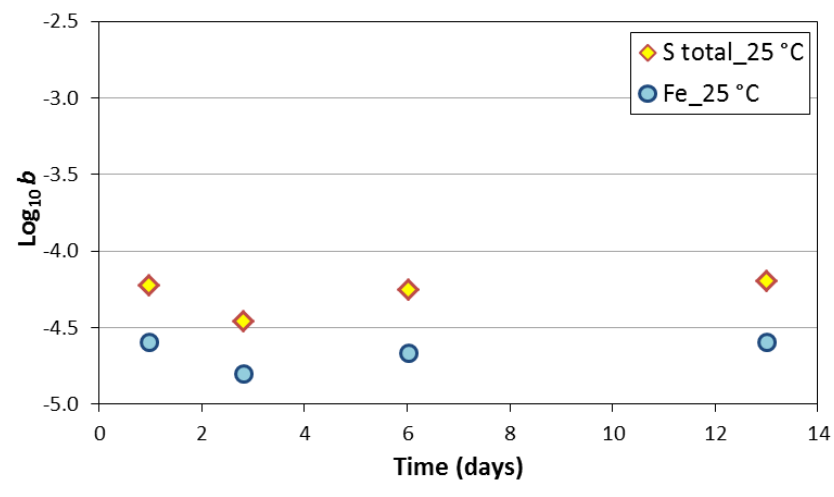

(c)

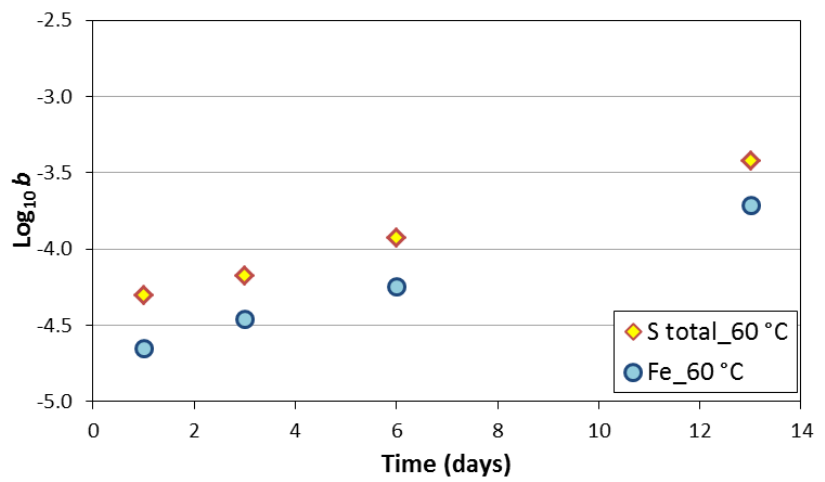

(b)

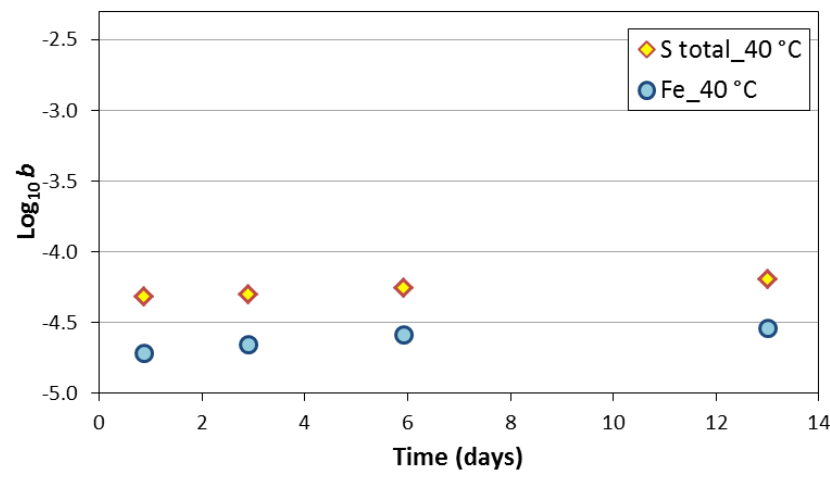

(d)

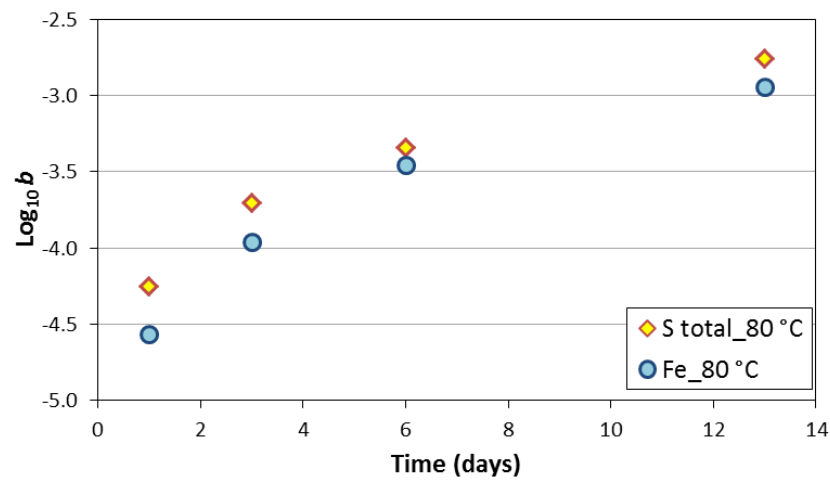

Figure 3: Determination of equilibration time for FeS

Table 3 Solubility data ${ }^{a}$ and their standard deviation ${ }^{b}$ for FeS at temperatures between 25 and $80^{\circ} \mathrm{C}$ at atmospheric pressure. Equilibration times between 1 and 13 days.

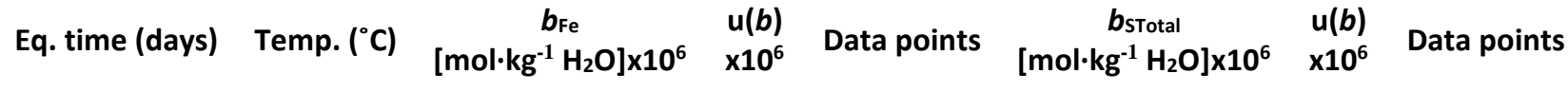

\begin{tabular}{cccccccc}
\hline 1 & $25^{\mathrm{c}}$ & 25.6 & 0.2 & 3 & 60.3 & 1.7 & 3 \\
& $40^{\mathrm{d}}$ & 19.5 & 0.5 & 3 & 48.9 & 0.8 & 3 \\
& $60^{\mathrm{e}}$ & 22.6 & 4.6 & 6 & 50.2 & 1.5 & 6 \\
& $80^{\mathrm{f}}$ & 27.1 & 3.5 & 6 & 56.1 & 4.5 & 6 \\
\hline 3 & 25 & 16.0 & 0.2 & 3 & 34.8 & 1.0 & 3 \\
& 40 & 22.1 & 0.8 & 6 & 50.3 & 9.3 & 6 \\
& 60 & 35.1 & 2.5 & 6 & 67.3 & 1.1 & 6 \\
& 80 & 109.3 & 2.2 & 6 & 198.1 & 9.8 & 6 \\
\hline & 25 & 21.7 & 1.2 & 6 & 56.0 & 5.0 & 6 \\
& 40 & 26.2 & 0.4 & 6 & 56.0 & 9.9 & 6
\end{tabular}




\begin{tabular}{rrrrrrrr} 
& 60 & 57.5 & 1.0 & 5 & 119.2 & 1.4 & 5 \\
& 80 & 349.3 & 15.0 & 6 & 454.8 & 34.3 & 6 \\
\hline \multirow{2}{*}{13} & 25 & 25.4 & 1.7 & 6 & 63.9 & 21.5 & 6 \\
& 40 & 29.1 & 1.4 & 6 & 65.0 & 10.4 & 5 \\
& 60 & 193.7 & 2.8 & 3 & 381.7 & 3.9 & 3 \\
& 80 & 1148.1 & 6.8 & 3 & 1739.9 & 7.0 & 3 \\
\hline
\end{tabular}

The results for $\mathrm{PbS}$ are presented in Figure 4. The data are reported in Table 4. The concentration of

a The concentrations, $b_{\mathrm{Fe}}$ and $b_{\text {STotal, }}$ correspond to the average of the data points reported.

$\mathrm{b}$ The standard deviation of the measured concentrations is reported as $\mathrm{u}(b)$

$\mathrm{c}, \mathrm{d}, \mathrm{e}, \mathrm{f}$ Standard uncertainties $\mathrm{u}(\mathrm{T})=0.23^{\circ} \mathrm{C} ; 1.1^{\circ} \mathrm{C} ; 0.18^{\circ} \mathrm{C}$ and $0.07^{\circ} \mathrm{C}$ for each of the four temperatures.

$\mathrm{Pb}$ and $\mathrm{S}$ remain constant over the range of time studied at $25{ }^{\circ} \mathrm{C}$ as observed in Figure $4 \mathrm{a}$. The constant concentration conditions suggest that equilibrium conditions are achieved in a matter of hours (less than one day) at $25^{\circ} \mathrm{C}$. (a)

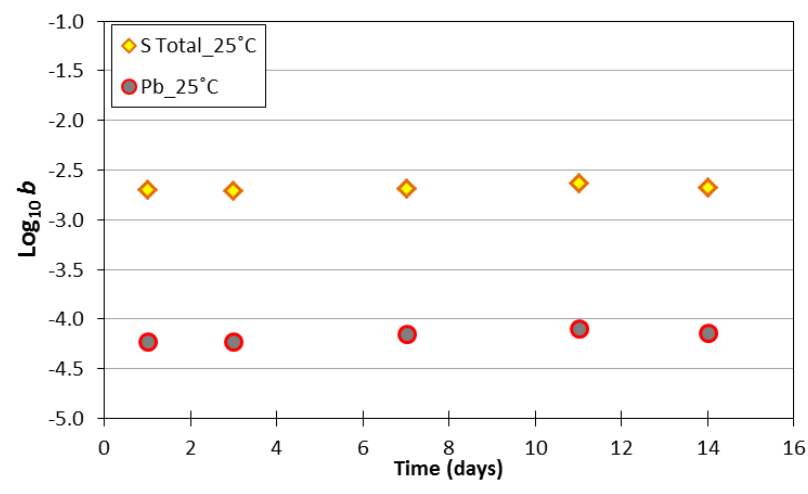

(c)

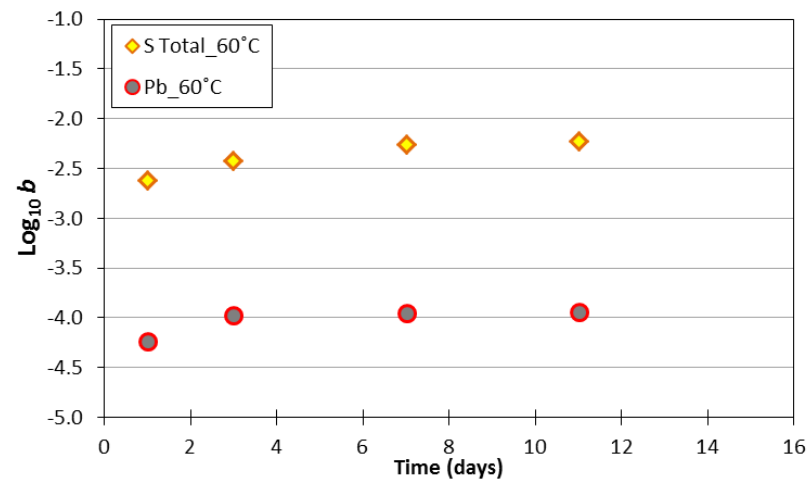

(b)

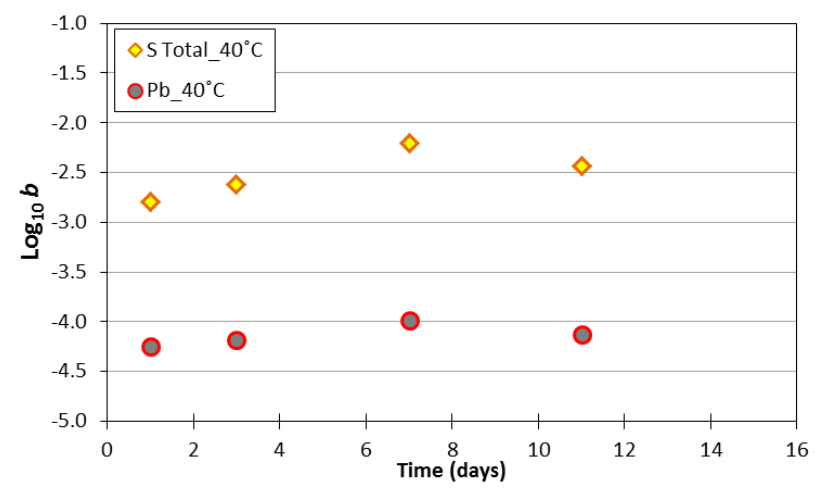

(d)

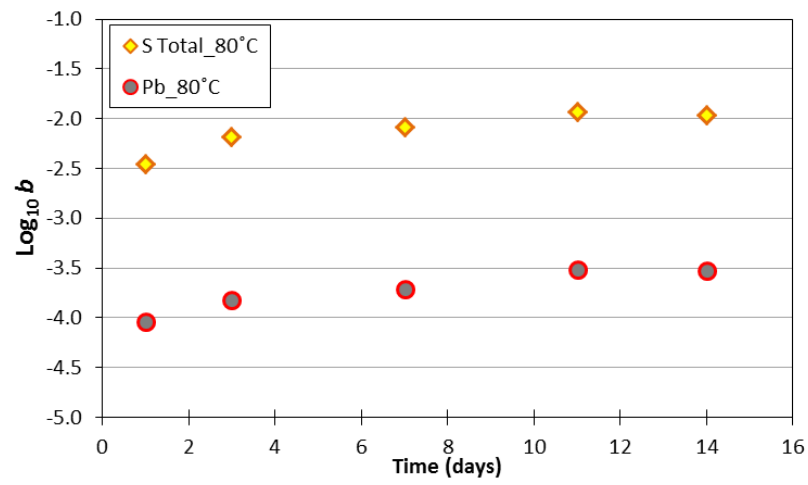

Figure 4: Determination of equilibration time for PbS

9 The scenarios at temperatures between 40 and $80{ }^{\circ} \mathrm{C}$ look slightly different. An increase in 10 concentration for $\mathrm{Pb}$ and $\mathrm{S}$ is observed between 1 and 7 days. Beyond 7 days, the figures exhibit a 11 plateau meaning that equilibrium conditions have been achieved. A significant difference between 12 the concentration of $\mathrm{Pb}$ and $\mathrm{S}$ is observed in this case. The concentration of total sulfur is 39 times 
1 higher than the concentration of $\mathrm{Pb}$. This observation cannot be attributed to the composition of the

2 initial solid. As mentioned in Section 2.1.1 the composition of the initial solid was determined to

3 correspond to stoichiometric PbS. A possible explanation of this difference in concentration is the

4 precipitation of $\mathrm{PbO}$ or $\mathrm{Pb}(\mathrm{OH})_{2}$. This would also explain a slight drop in $\mathrm{pH}$ during the equilibrium

5 experiment (see Table 5). The difference between the concentrations of metal ion and of total sulfur

6 was observed as well in an earlier study on ZnS Figueroa et al. [21]. No evidence of contamination

7 nor use of non-stoichiometric ZnS could explain the differences in concentration observed between

$8 \quad \mathrm{Zn}$ and total S Figueroa et al. [21].

9 Table 4 Solubility data ${ }^{\mathrm{a}}$ and their standard deviation ${ }^{\mathrm{b}}$ for $\mathrm{PbS}$ at temperatures between 25 and $80{ }^{\circ} \mathrm{C}$ at atmospheric 10 pressure. Equilibration times between 1 and 14 days.

\begin{tabular}{|c|c|c|c|c|c|c|c|}
\hline Eq. time (days) & Temp. $\left({ }^{\circ} \mathrm{C}\right)$ & $\begin{array}{c}b_{\mathrm{Pb}} \\
{\left[\mathrm{mol} \cdot \mathrm{kg}^{-1} \mathrm{H}_{2} \mathrm{O}\right] \times 10^{6}}\end{array}$ & $\begin{array}{l}u(b) \\
x 10^{6}\end{array}$ & Data points & $\begin{array}{c}b_{\text {STotal }} \\
{\left[\mathrm{mol} \cdot \mathrm{kg}^{-1} \mathrm{H}_{2} \mathrm{O}\right] \times 10^{6}}\end{array}$ & $\begin{array}{l}u(b) \\
x 10^{6}\end{array}$ & Data points \\
\hline \multirow[t]{4}{*}{1} & $25^{c}$ & 6.0 & 0.4 & 8 & 2.0 & 0.1 & 8 \\
\hline & $40^{d}$ & 5.7 & 0.4 & 7 & 1.6 & 0.1 & 6 \\
\hline & $60^{e}$ & 5.8 & 0.5 & 9 & 2.4 & 0.2 & 9 \\
\hline & $80^{f}$ & 9.0 & 1.0 & 5 & 3.5 & 0.3 & 6 \\
\hline \multirow[t]{4}{*}{3} & 25 & 5.9 & 0.4 & 17 & 2.0 & 0.1 & 16 \\
\hline & 40 & 6.6 & 1.0 & 11 & 2.4 & 0.4 & 12 \\
\hline & 60 & 10.5 & 0.5 & 7 & 3.7 & 0.1 & 9 \\
\hline & 80 & 14.9 & 0.3 & 7 & 6.5 & 0.7 & 6 \\
\hline \multirow[t]{4}{*}{7} & 25 & 7.1 & 0.5 & 6 & 2.1 & 0.2 & 8 \\
\hline & 40 & 10.3 & 2.7 & 6 & 6.2 & 3.0 & 6 \\
\hline & 60 & 11.1 & 0.3 & 8 & 5.5 & 0.6 & 7 \\
\hline & 80 & 19.2 & 0.9 & 9 & 8.3 & 0.3 & 7 \\
\hline \multirow[t]{4}{*}{11} & 25 & 8.0 & 0.3 & 8 & 2.4 & 0.1 & 4 \\
\hline & 40 & 7.5 & 0.3 & 7 & 3.7 & 0.3 & 7 \\
\hline & 60 & 11.6 & 0.8 & 7 & 5.9 & 0.8 & 6 \\
\hline & 80 & 30.6 & 2.0 & 5 & 11.8 & 1.2 & 6 \\
\hline \multirow[t]{2}{*}{14} & 25 & 7.3 & 0.2 & 7 & 2.1 & 0.3 & 7 \\
\hline & 80 & 29.9 & 1.4 & 7 & 10.9 & 0.1 & 7 \\
\hline
\end{tabular}

a The concentrations $b_{P b}$ and $b_{\text {STotal }}$ correspond to the average of the data points reported.

b The standard deviation of the measured concentrations is reported as $u(b)$

$c, d, e, f$ Standard uncertainties $\mathrm{u}(\mathrm{T})=0.04^{\circ} \mathrm{C} ; 0.74{ }^{\circ} \mathrm{C} ; 0.56^{\circ} \mathrm{C}$ and $0.01{ }^{\circ} \mathrm{C}$ for each of the four temperatures.

Table $5 \mathrm{pH}$ values for PbS solubility measurements

\begin{tabular}{rrrrrr}
\hline $\begin{array}{c}\text { Temperature } \\
\left({ }^{\circ} \mathrm{C}\right)\end{array}$ & $\begin{array}{c}\text { Eq. time } \\
\text { (days) }\end{array}$ & & pH & \\
\hline 25 & 7 & 5.25 & \pm & 0.1
\end{tabular}




$\begin{array}{rrrll}25 & 14 & 4.86 & \pm & 0.6 \\ 40 & 1 & 4.38 & \pm & 0.0 \\ 80 & 1 & 5.32 & \pm & 0.3 \\ 80 & 14 & 5.39 & \pm & 0.1\end{array}$

3 The effect of temperature on the solubility of FeS is presented in Figure 5 . The results are plotted as 4 molality $b_{\mathrm{FeS}}\left(\mathrm{mol} \cdot \mathrm{kg}_{\text {water }}{ }^{-1}\right)$ versus temperature and are compared with published data for FeS 5 solubility. FeS solubility was taken to be equal to the Fe molality. Differences in the starting material 6 in earlier data are indicated in Figure 5 since direct comparison cannot be done due to differences in crystal structure and composition.

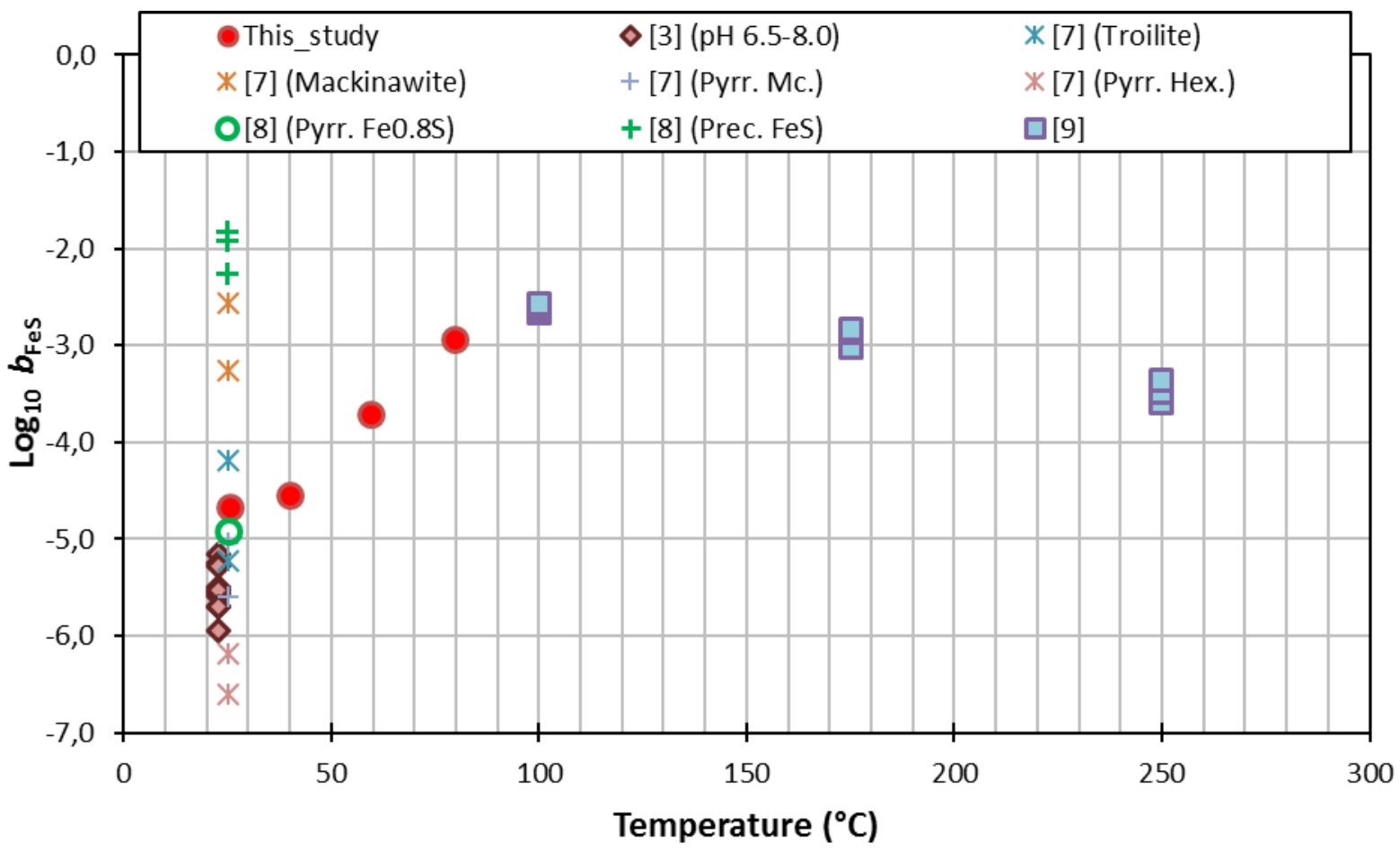

Figure 5: Effect of temperature on FeS solubility in aqueous solution.

Data taken from Rickard [3]; Tewari et al. [7] for pyrrhotite hexagonal, mackinawite, pyrrhotite monoclinic and troilite; at $\mathrm{pH}$ between 6.5 and 8.0; Berner [8] for pyrrhotite and precipitated FeS; Yan et al. [9] in $1 \mathrm{M} \mathrm{NaCl}$ solution.

The results obtained in this study for FeS solubility indicate that the solubility of FeS increases linearly as temperature increases (except for the data point obtained at $25^{\circ} \mathrm{C}$ ). The solubility of FeS increases approximately 54 times at $80^{\circ} \mathrm{C}$ compared to solubility data obtained at $25^{\circ} \mathrm{C}$. 
The majority of the data for FeS solubility found in literature are measured at $25{ }^{\circ} \mathrm{C}$. The high scattering observed in the data at $25{ }^{\circ} \mathrm{C}$ is mainly due to the different composition and crystal structure of the initial solid material. The data presented in Figure 5 differ in $\mathrm{pH}$, salinity and crystal structure. Thus, this comparison is intended only for descriptive purposes. Tewari et al. [7] measured the solubility of 4 different types of iron sulfide. As it can be seen in Figure 5 the most soluble form of FeS used by Tewari et al. [7] was Mackinawite and the least was pyrrhotite with hexagonal crystal structure. The value presented by Berner [8] and the data points published by Tewari et al. [7] at 25 ${ }^{\circ} \mathrm{C}$ of hexagonal pyrrhotite are comparable to our value since the starting material has a similar composition and crystal structure. The value presented by Berner [8] is expected to exhibit a high value of solubility since it was measured in aqueous solutions previously saturated with $\mathrm{H}_{2} \mathrm{~S}$. Our value at $25^{\circ} \mathrm{C}$ is slightly larger than the value presented by Berner [8] but the trend observed for our data matches with the data point reported by Berner [8]. Compared to the data published by Tewari et al. [7] our value is approximately 23 times larger. The values obtained by Tewari et al. [7] were measured in the presence of $\mathrm{H}_{2} \mathrm{~S}$ and it was expected that our value is lower. Apart from the two studies by Berner [8] and Tewari et al. [7] discussed earlier, comparison with other studies is challenging. The solubility data reported by Yan et al. [12] were obtained using troilite in an aqueous solution of $1 \mathrm{M} \mathrm{NaCl}$. Troilite exhibits higher solubility values than pyrrhotite as observed in the data published by Tewari et al. [7].

The solubility for $\mathrm{PbS}$ as a function of temperature is presented in Figure 6 . The tendency of the solubility of $\mathrm{PbS}$ is to increase as temperature increases. The increase is not as remarkable as observed in the case of FeS. The solubility of PbS increases 3 times by increasing temperature from $25^{\circ} \mathrm{C}$ to $80^{\circ} \mathrm{C}$. To better understand the results obtained in this study, our results are compared with previously published data. The data available in literature are scarce and differ slightly between authors in terms of $\mathrm{pH}$ and salinity (among variations during the experimental procedures). Therefore, direct comparison may not be appropriate but it brings insights regarding the behavior of $\mathrm{PbS}$ in aqueous solutions.

The majority of published data for PbS solubility were obtained at $25^{\circ} \mathrm{C}$. This is the case of Biltz [23] Nims and Bonner [18], and Weigel [17]. Biltz [23] and Weigel [17] measured the solubility of freshly precipitated PbS while Nims and Bonner [18] measured the solubility of the mineral form. The value reported by Nims and Bonner [18] is expected to be lower (as reported in Figure 6) as the mineral form was used. The mineral form of aged PbS has a more stable structure that tends to be less soluble 
1 in water. Our value obtained at $25{ }^{\circ} \mathrm{C}$ is 20 times higher than the values obtained by Biltz [23] and

2 Weigel [17]. The initial material in three of the cases is precipitated PbS like we used in our work, and

3 there is not a clear reason why our solubility value is higher. It could be expected that the value 4 reported by e.g. Weigel [17] was higher than the one reported here since measurements of the solubility were done by means of conductivity. Conductivity measurements could overestimate the contribution of $\mathrm{Pb}$ ions as impurities could add to the conductivity value.

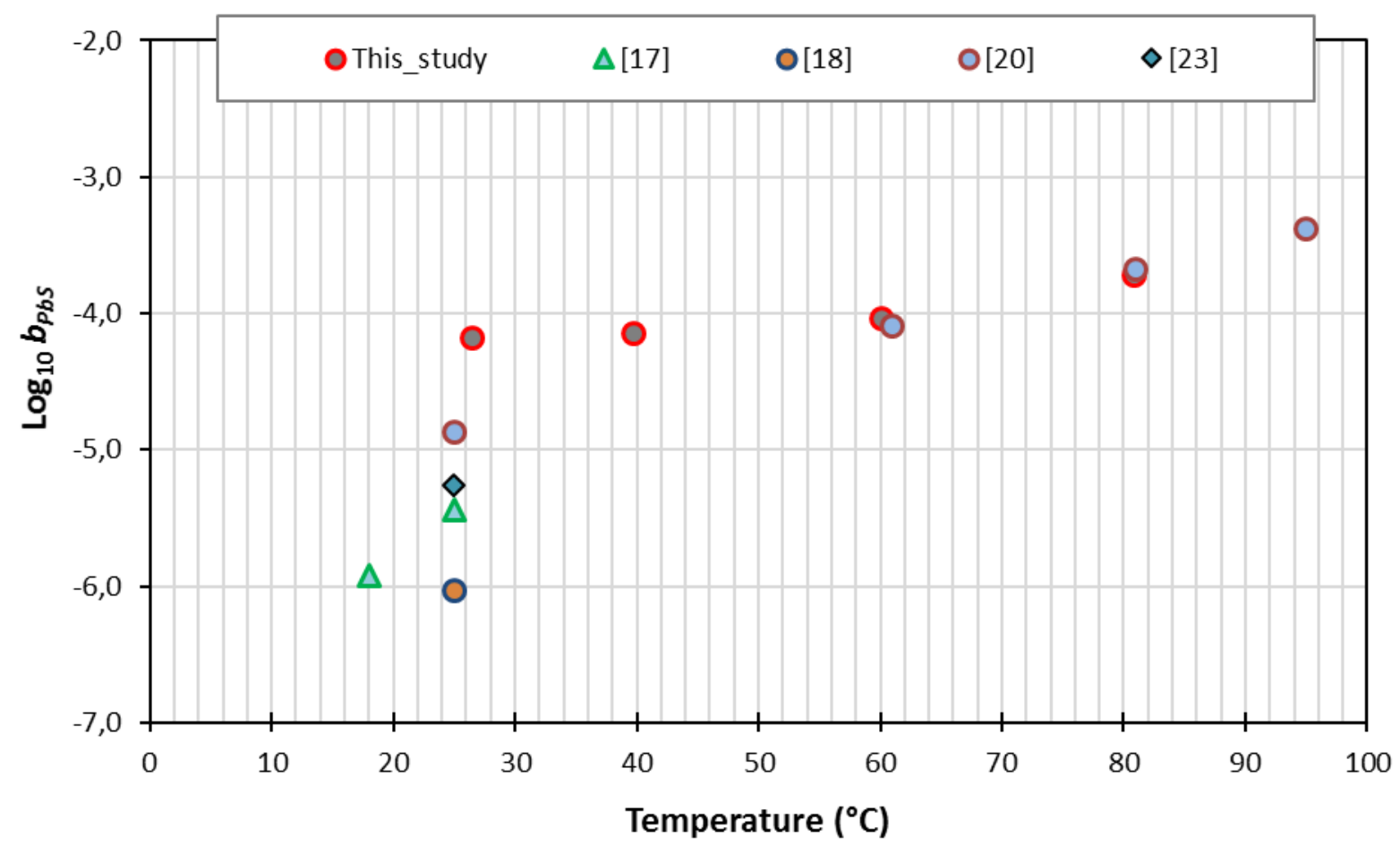

The values reported here are comparable to those obtained by Barrett and Anderson [20], in $3 \mathrm{M}$ $\mathrm{NaCl}$ solutions. Data obtained from, Weigel [17], Nims and Bonner [18], Barrett and Anderson [20] and Biltz [23]

Our data were carefully measured using the appropriate pore size for the filtration membrane and the presence of impurities was tested without finding contaminating $\mathrm{Pb}$ sources.

PbS exhibits higher solubility at low temperatures $\left(25-40^{\circ} \mathrm{C}\right)$ than FeS. At higher temperatures $(40$ $100{ }^{\circ} \mathrm{C}$ ) FeS is more soluble than PbS. Besides, the effect of temperature on solubility is more remarkable for FeS than in $\mathrm{PbS}$. 
1 The error estimation of the measurements was determined using standard solutions of the elements studied here. The error was estimated using Eq. (2). The relative error estimated for the reported Fe concentrations oscillates between $0.4 \%$ and $2.9 \%$ and $\mathrm{Pb}$ between $1.4 \%$ and $2.8 \%$. For total sulfur the error estimate oscillates between $1.1 \%$ and $2.9 \%$.

\section{Conclusions}

6 The solubility of $\mathrm{FeS}$ and $\mathrm{PbS}$ was measured in aqueous solutions at temperatures between $25^{\circ} \mathrm{C}$ and

$780^{\circ} \mathrm{C}$ and atmospheric conditions. The experiments were carried out using solid forms of FeS and $\mathrm{PbS}$

8 obtained from a supplier. The purity of the solid materials was confirmed by XRD analysis. The results

9 indicated that the FeS was deficient in Fe corresponding to pyrrhotite. The spectrum for PbS showed

10 that the initial solid was galena with stoichiometric composition. The solid materials were clearly

11 identified and the solubility behaviour was analysed based on their characteristics. The experiments

12 were run at the natural $\mathrm{pH}$ in an inert atmosphere.

13 The time required for reaching equilibrium was explored by running experiments at extended times 14 (14 days). It was found that FeS in aqueous solution reached equilibrium in around 6 days. Variations in time were observed at different temperatures. It was concluded that equilibrium conditions are 16 achieved faster at low temperatures $\left(25-40^{\circ} \mathrm{C}\right)$ than at higher temperatures $\left(60-80^{\circ} \mathrm{C}\right)$. Meanwhile 17 for the $\mathrm{PbS}$ system equilibrium conditions at $25^{\circ} \mathrm{C}$ were apparently achieved in a matter of less than 24 hours. At higher temperatures (up to $80^{\circ} \mathrm{C}$ ) it was found that the time required for equilibrium did not vary much. If particles smaller than the pores of the filter are present, they will influence the ICP-OES measurement and produce erroneous results. Therefore, it is recommended to run a particle size analysis to determine the required pore size of the membrane prior solubility analysis.

The solubility as a function of temperature was explored in the range between 25 and $80{ }^{\circ} \mathrm{C}$. The solubility of $\mathrm{FeS}$ and $\mathrm{PbS}$ in aqueous solution both increase with increasing temperature. The effect 24 is highest for FeS. The solubility of FeS at $80^{\circ} \mathrm{C}$ was observed to be 54 times higher than at $25^{\circ} \mathrm{C}$. Meanwhile, the solubility of PbS just increased 3 times by increasing the temperature from 25 to 80 ${ }^{\circ} \mathrm{C}$. 


\section{Acknowledgment}

2 This work was carried out as part of the NextOil DK project (New Extreme Oil and Gas in the Danish 3 North Sea). The NextOil project received funding from the Danish Advanced Technology Fund (HTF 4 j.nr.: 113-2012-1), DONG E\&P, and Maersk Oil.

5 We thank M.Sc. student Petter Loms $\varnothing y$ for his contribution to the measurements for the PbS 6 aqueous system. 
[1] B.N. Herbert, P.D. Gilber, H. Stockdale, R.J. Watkinson, Factors controlling the activity of sulphatereducing bacteria in reservoirs during water injection, Society of Petroleum Engineers SPE13978/1 (1985).

[2] P. May, D. Batka, G. Hefter, E. Konigsberger, D. Rowland, Goodbye to $\mathrm{S}^{2-}$ in Aqueous Solution, Chem. Commun. 54 (2018) 1980-1983. doi:10.1039/C8CC00187A.

[3] D. Rickard, The solubility of FeS, Geochim. Cosmochim. Acta. 70 (2006) 5779-5789.

[4] W. Davison, The solubility of iron sulphides in synthetic and natural waters at ambient temperature, Aquat. Sci. 53 (1991) 309-329.

[5] H. Nasr-El-Din, A. Al-Humaidan, Iron Sulfide Scale: Formation Removal and Prevention, Int. Symp. Oilf. Scale. (2001) 13. doi:10.2523/68315-MS.

[6] D. Rickard, G.W. Luther, Chemistry of iron sulfides, Chem. Rev. 107 (2007) 514-562.

[7] P.H. Tewari, G. Wallace, A.B. Campbell, The solubility of iron sulfides and their role in mass transport in Girdler-sulfide heavy water plants, Atomic Energy of Canada Ltd., 1978. AECL-5960.

[8] R.A. Berner, Thermodynamic stability of sedimentary iron sulfides, Am. J. Sci. 265 (1967) 773-785.

[9] C. Yan, P. Guraieb, R.C. Tomson, Solubility Study of Iron Sulfide FeS Under Extremely High Temperature Pressure in Strictly Anoxic, Various Ionic Strength Solutions, in: SPE Int. Oilf. Scale Conf. Exhib., Society of Petroleum Engineers, 2016.

[10] J.I. Al-Tammar, M. Bonis, H.J. Choi, Y. Al-Salim, Saudi Aramco Downhole Corrosion/Scaling Operational Experience and Challenges in HP/HT Gas Condensate Producers, (2014). doi:10.2118/169618-MS.

[11] M.A. Kasnick, R.J. Engen, Iron Sulfide Scaling and Associated Corrosion in Saudi Arabian Khuff Gas Wells, Middle East Oil Show. SPE 17933 (1989). doi:10.2118/17933-MS.

[12] A.J. Savin, B. Adamson, J.J. Wylde, J.R. Kerr, C.W. Kayser, T. Trallenkamp, D. Fischer, C. Okocha, Sulfide Scale Control: A High Efficacy Breakthrough Using an Innovative Class of Polymeric Inhibitors, SPE Int. Oilf. Scale Conf. Exhib. (2014). doi:10.2118/169777-MS.

[13] S. Baraka-Lokmane, C. Hurtevent, H. Zhou, P. Saha, N. Tots, F. Rieu, TOTAL's Experience on the Development and Implementation of a Scale Management Strategy in Central Graben Fields, Soc. Pet. 
Eng. (2014) 1-17. doi:10.2118/169757-MS.

[14] M.M. Jordan, K. Sjursaether, M.C. Edgerton, R. Bruce, Inhibition of Lead and Zinc Sulphide Scale Deposits Formed during Production from High Temperature Oil and Condensate Reservoirs., in: SPE Asia Pacific Oil Gas Conf. Exhib., Society of Petroleum Engineers, 2000.

[15] C. Okocha, K. Sorbie, Scale Prediction for Iron, Zinc and Lead Sulphides and Its Relation to Scale Test Design, Corros. 2014. (2014) Paper No 3766. doi:10.2118/164111-MS.

[16] H.L. Clever, F.J. Johnston, The solubility of some sparingly soluble lead salts: an evaluation of the solubility in water and aqueous electrolyte solution, J. Phys. Chem. Ref. Data. 9 (1980) 751-784.

[17] O. Weigel, The solubility of the sulphides of the heavy metals in water, Z. Phys. Chem. 58 (1907) 293300.

[18] L.F. Nims, W.D. Bonner, The Solubility of Galena and a Study of Some Lead Concentration Cells, J. Phys. Chem. 33 (1929) 586-590.

[19] R.J. Hamann, G.M. Anderson, Solubility of galena in sulfur-rich $\mathrm{NaCl}$ solutions, Econ. Geol. 73 (1978) 96-100.

[20] T.J. Barrett, G.M. Anderson, The solubility of sphalerite and galena in 1-5 m NaCl solutions to $300 \mathrm{C}$, Geochim. Cosmochim. Acta. 52 (1988) 813-820.

[21] D.C. Figueroa, P.L. Fosbøl, K. Thomsen, Determination of Zinc Sulfide Solubility to High Temperatures, J. Solution Chem. 46:1805 (2017). doi:10.1007/s10953-017-0648-1.

[22] R. Jones, Particle size analysis by laser diffraction: ISO 13320, Am. Lab. 35 (2003).

[23] W. Biltz, Experiments on ultramicroscopic determination of solubility, Z. Phys. Chem. 58 (1907) 288292.

[24] PerkinElmer Inc., Syngistix ${ }^{\mathrm{TM}}$, Interface for Avio Model 200 ICP-OES, Product No: N0780203, (2017) 